\title{
Managing krill in the Southern Ocean
}

THROUGHOUT next month, the thirteen signatories of the Antarctic Treaty will meet in private in Canberra, Australia to negotiate a convention to control the exploitation of krill - commonly regarded as the Antarctic's most immediately exploitable resource. Krill are small shrimp-like creatures which thrive in great abundance in the extraordinarily nutrientrich cold waters of the Southern Ocean. They are central to maintaining the ecological balance of the Antarctic because they feed on abundant phytoplankton and in turn are fed on by many larger animals; in particular they form the staple food of whales. They are also increasingly being recognised as a potetial source of protein for man. Hence the need for a convention which controls man's exploitation in such a way as to be non-discriminatory between different nations and at the same time maintain the local eco-system.

The Antarctic Treaty states have been negotiating the 'krill convention' Convention on the Conservation of Antarctic Marine Living Resources in secret - for several years. Next month's meeting is hoped to be the last: agreement on the text of the convention should be reached, although ratification could take up to ten subsequent years.

The success of the convention, however, will also depend upon how acceptable it is to other nations not involved in its negotiation but nevertheless interested in reaping some of the benefit of the opening up of new fishing grounds. In particular, several developing countries have expressed fears that the convention only takes into account the interests of the
Antarctic Treaty signatories and other countries which are technologically capable of fishing in the extreme conditions of the Antarctic. The secrecy of the negotiations has not helped to dispel such fears and some observers, in particular the authors of a report published by the International Institute for Environment and Development (IIED)* last week, believe that agreement on the convention may spark off a wider international debate on the rights of access to the fishing grounds.

Reaching some sort of agreement just among the Antarctic Treaty signatoires, however, will not have been easy. The key problem has been how to cope with the territorial claims of some nations to large slices of the Antarctic continent together with 200 mile-wide coastal strips of sea. Those signatories who have not laid claim to land do not recognise the claims of the others. The problem has therefore been to work out a 'bifocal' approach which leaves open the question of sovereignty over coastal fishing grounds.

The political problems of negotiating the convention are certainly great - but there are also many scientific problems to be solved before a system of good management for the Southern Ocean can be established. As yet there are no relaible estimates of the amount of krill which could be caught annually on a sustainable basis. There is also insufficient information on the interaction of different species living in the area.

The scientific problems implicit in the krill convention are different from those associated with other fisheries agreements because of the nature of the convention's prime objective - the conservation of marine living resources. This is a totally new approach to fisheries control according to Dr John Beddington of York University who helped the IIED prepare its report. Previous agreements have mainly been concerned with the optimization of harvesting by man.

Although Dr Beddington regards the spirit of the convention on conservation as worthy, he is critical of its scientific approach. In particular, it does not take into account the fact that the net greatest annual increment in a population can be achieved only by removing its predators. In the case of krill this would mean killing whales - a contradiction of the convention's aim of allowing depleted whale populations to recover.

The IIED report recommends alterations to the wording of the convention to eliminate this contradiction. It also suggests that the scientific committee which is to be set up under the convention to provide scientific information, should maintain close links with independent scientists. However, the BIOMASS (the Biological Investigation of Marine Antarctic Systems and Stocks) programme, managed under the aegis of the International Council of Scientific Unions, should remain independent from the scientific machinery of the convention, it says. It should supply independent scientific information, free from any political constraints.

Judy Redfearn

*The Management of the Southern Ocean Barbara Mitchell and Richard Sandbrook, IIED, 10, Percy Street, London WIP ODR. £2.

\section{Energy}

\section{France plans one third nuclear energy by 1990}

A confident forecast by the French Ministry of Industry has predicted that by 1990 France will have cut its dependence on oil to one third of its primary energy demand. It will do this, says the ministry, mostly by a dramatic ten-fold increase in the use of nuclear power, but also through contributions from gas and renewable energies - particularly solar and geothermal. The renewable contribution must increase four-fold in the next ten years to meet the ministries' targets.

France already makes considerable use of hot springs for household heating. All renewable resources (other than hydro) together now contribute only $1.5 \%$ of France's annual 323 million tonnes of coal equivalent energy demand, but, says an official communique of the council of ministers "certain renewable resources will come to maturity" in the next decade.

These projections considerably exceed those, say, of the UK, where energy minister David Howell told the Select Committee on Energy recently that "the contribution from renewable sources in the year 2000 might be up to 10 mtce. My department now considers that this is, if anything, an overestimate". $10 \mathrm{mtce}$ would be $2.5 \%$ of total energy use in 2000 .

UK nuclear projections are also much smaller, a doubling to $9 \%$ of demand by 1990 , compared to France's $30 \%$ by the same date. France must build one reactor every two months to reach its target.

According to Le Monde (4 April) the government expects that a $£ 6$ billion investment in energy conservation in industry by 1990 will save 10 mtce per year.

Moreover to encourage those living near the sites of projected nuclear power stations to accept their lot, electricity supplies will be set 12 to $17 \%$ cheaper for those living "in the vicinity" of the power station.

However not all are happy with the plans. Le Monde quotes M. Michel Rolant, national secretary of the giant trade union CFDT, as saying that while it is desirable to reduce dependence on oil " $i$ is dangerous to make this objective dependent on the imposition of electrical energy on all domains other than transport''. The plans imply that in $199042 \%$ of French primary energy will be converted to electricity, $73 \%$ of that being produced by nuclear power stations. At present about $30 \%$ of French primary demand goes to electricity generation.

Moreover, said Rolant, France is taking a formidable bet on the good performance of the 66 or so nuclear reactors it will need in operation by 1990 .

The cost of this programme $-£ 26$ billion according to Rolant - "is so large that it will make it impossible to follow a serious programme of energy conservation, or of the development of renewable sources..." 